\title{
Effect of gravity and gas flow direction on the operation of Polymer Electrolyte Membrane Fuel Cells
}

\author{
Vinh Nguyen Duy, Hyung-Man Kim ${ }^{*}$ \\ Department of Mechanical Engineering \& High Safety Vehicle Core Technology Research Center, \\ INJE University, 607 Eobang-dong, Gimhae-si, Gyongsangnam-do 621-749, Republic of Korea \\ *E-mail: mechkhm@inje.ac.kr
}

doi: $10.20964 / 2017.12 .78$

Received: 26 July 2017 / Accepted: 20 September 2017 / Published: 12 November 2017

\begin{abstract}
The flow-field designs of bipolar plates (BPs) contribute to improving the fuel cell performance. However, the acceleration due to gravity and the direction of supplied gas flows also directly affects fuel cell operation, because they result in transportation phenomena, the uniform distribution of reacting gases, and water management. This research focused on analyzing the effects of gravity and gas flow direction on fuel cell operation. In addition, the constant stoichiometry and constant mass flow rate boundary condition applied for fuel cell operation, were also analyzed to determine the best conditions for fuel cell performance enhancement. The results showed that proton exchange membrane fuel cells (PEMFCs) performance can be dramatically improved by optimizing the gravitational angle and the supplied gas flow direction. Consequently, when the air and hydrogen gas inlets are both placed at the upper side, the fuel cell performance can be enhanced up to $5 \%$ in comparison with those placed at the lower side. Furthermore, when the gas direction between adjacent channels is alternatively changed in the interleaved flow configuration, the fuel cell performance is dramatically enhanced compared to other flow types. The counter-flow type configuration exhibited the worst ability to improve fuel cell performance because it plays a vague role in distributing gases and liquid water over the fuel cell. The maximum difference in power density among various flow types at the same current density ranges up to approximately $17 \%$.
\end{abstract}

Keywords: Proton exchange membrane fuel cell; Gravitational force; Convection and Diffusion, gas flow direction; Polarization performance

\section{$\underline{\text { FULL TEXT }}$}

(C) 2017 The Authors. Published by ESG (www.electrochemsci.org). This article is an open access article distributed under the terms and conditions of the Creative Commons Attribution license (http://creativecommons.org/licenses/by/4.0/). 